\title{
Konsekuensi Yuridis Terhadap Diabaikannya Pelaksaan Putusan Pengadilan Tata Usaha Negara Yang Telah Memiliki Kekuatan Hukum Tetap
}

\author{
Saartje Sarah Alfons \\ Fakultas Hukum Universitas Pattimura, Ambon, Indonesia \\ E-mail: saartjealfons@gmail.com
}

\begin{abstract}
Unlawful Consequences of Justice in the execution of the decision of the State Administration court by government officials, are arbitrary and contempt of court actions which may be subject to administrative sanctions as well as unlawful acts that may be sued in civil courts.
\end{abstract}

Keywords: Legal Justice, Decision of State Administrative Court

\section{A. PENDAHULUAN}

Indonesia sebagai Negara hukum di atur dalam pasal 1 ayat (3) UUD NRI Tahun 1945. Pelaksanaan konsep Negara hukum membuat pembagian kekuasaan menjadi salah satu bagian yang berperan dalam penyelenggaraan pemerintahan. Dimana, pembagian kekuasaan memungkinkan adanya pembatasan dalam penyelenggaraan kekuasaan. Ide pembatasan kekuasaan dianggap harus ada supaya kekuasaan negara tidak terpusat di tangan satu orang atau satu organ saja.

Pandangan tersebut merupakan wujud dari implementasi Negara hukum apabila, pertama, kekuasaan dibagi ke dalam berbagai cabang (separation of power), dan kedua, antar institusi negara yang memiliki kekuasaan yang berbeda tersebut diperbolehkan untuk saling mengontrol (check and balance system $)^{1}$.

Berdasarkan hal tersebut, maka gagasan Negara Hukum dibangun dengan mengembangkan perangkat hukum itu sendiri sebagai suatu sistem yang fungsional dan berkeadilan, dikembangkan dengan menata supra struktur dan infra struktur kelembagaan politik, ekonomi dan sosial yang tertib dan teratur, serta dibina dengan membangun budaya dan kesadaran hukum yang rasional dan impersonal dalam kehidupan bermasyarakat, berbangsa dan bernegara ${ }^{2}$.

${ }^{1}$ Rikardo, Simarmata, 2012. Pemenuhan indikator Negara Hukum dalam putusan pengadilan berkaitan dengan sumber daya alam dan lingkungan hidup, Kertas Kerja Epistema No.10/2012, Epistema Institute, Jakarta: (http://epistema.or.id/indikator $\square$ negara $\square$ hukum), h. 2. (Diakses pada Tanggal 28 Mei 2018)

2 Jimly Asshiddiqie, Gagasan Negara Hukum Indonesia, http://www.docudesk.com. (Diakses pada Tanggal 28 Mei 2018) 
Terkait dengan unsur peradilan administrasi, maka keberadaanya di dasarkan pada pemikiran bahwa negara sebagai subjek hukum yang tidak kebal hukum atau dapat bebas dari hukum. Sebagai subjek negara, maka negara merupakan pribadi hukum yang memiliki hak dan kewajiban seperti subjek hukum yang lain. Dimana dalam melakukan hubungan-hubugan hukum, maka negara dapat melakukan perbuatan yang merugikan kepada subjek hukum yang lain, untuk itu dapat dimintai pertanggungjwabannya atas tindakannya tersebut di hadapan pengadilan ${ }^{3}$.

Dengan demikian, dalam setiap Negara Hukum terbuka kesempatan bagi tiap-tiap warga negara untuk menggugat keputusan pejabat administrasi Negara dan dijalankannya putusan hakim tata usaha Negara (administrative court) oleh pejabat administrasi negara. Pengadilan Tata Usaha Negara (PTUN) ini penting disebut tersendiri, karena PTUN yang menjamin agar warga negara tidak didzalimi oleh keputusan-keputusan para pejabat administrasi Negara sebagai pihak yang berkuasa. Jika hal itu terjadi, maka harus ada pengadilan yang menyelesaikan tuntutan keadilan itu bagi warga Negara, dan harus ada jaminan bahwa putusan hakim tata usaha Negara itu benar-benar djalankan oleh para pejabat tata usaha Negara yang bersangkutan. Sudah tentu, keberadaan hakim peradilan tata usaha negara itu sendiri harus pula dijamin bebas dan tidak memihak sesuai prinsip 'independent and impartial judiciary' ${ }^{4}$.

Dengan demikian, Negara Indonesia sebagai negara hukum yang salah satunya terdapat sistem peradilan yang bebas, dimana dalam sistem

3 Sibuea, Hotma. (2010). Asas Negara Hukum, Peraturan kebijakan dan Asas-asas Umum Pemerintahan Yang Baik, Jakarta: Erlangga, h. 32

4 Asshiddiqie, Jimly Gagasan Negara Hukum Indonesia, http://www.docudesk.com. (Diakses pada Tanggal 28 Mei 2018) peradilan yang bebas pelaksanaan suatu putusan pengadilan merupakan hal yang terpenting demi menegakkan supremasi hukum dan kepastian hukum. Seharusnya apapun resiko yang didapat suatu putusan pengadilan wajiblah untuk dilaksanakan. Namun dalam perkembangan dibentuknya Peradilan Tata Usaha Negara (PTUN) di Indonesia, memiliki kelemahan pada kekuatan hukum Putusan PTUN.

Terkait dengan hal tersebut, maka diharapkan agar keberadaan Badan/Pejabat Tata Usaha Negara (TUN) dalam melaksanakan putusan pengadilan tata usaha negara secara sukarela, guna mewujudkan asas kepastian hukum. Akan tetapi, dalam pelaksanaannya, keberhasilan pelaksanaan putusan tersebut sangat bergantung pada wibawa pengadilan dan kesadaran hukum para pejabat yang mengeluarkan keputusan TUN yang merupakan objek sengketa tersebut ${ }^{5}$.

Dalam perkembangannya, dengan berlakunya Undang-Undang No. 51 Tahun 2009 tentang Perubahan Kedua Atas Undang-Undang No. 5 Tahun 1986 tentang Peradilan Tata Usaha Negara diatur mengenai bagian-bagian baru pada Peradilan Tata Usaha Negara yang sebelumnya tidak diatur oleh Undang-Undang No. 5 Tahun 1986, khususnya pada Pasal 116, mengenai Pelaksanaan Putusan Pengadilan, yaitu:

1) Salinan putusan Pengadilan yang telah memperoleh kekuatan hukum tetap, dikirimkan kepada para pihak dengan surat tercatat oleh Panitera Pengadilan setempat atas perintah Ketua Pengadilan yang mengadilinya dalam tingkat pertama selambat-lambatnya dalam waktu empat belas hari.

2) Dalam hal empat bulan setelah putusan Pengadilan yang telah memperoleh kekuatan hukum

5 Abdullah, Rozali. (2005). Hukum Acara Peradilan Tata Usaha Negara. Jakarta: RajaGrafndo Persada, h. 99. 
tetap sebagaimana dimaksud dalam ayat (1) diterima tergugat tidak melaksanakan kewajibannya sebagaimana dimaksud dalam Pasal 97 ayat (9) huruf a, maka Keputusan Tata Usaha Negara yang disengketakan itu tidak mempunyai kekuatan hukum lagi.

Berdasarkan ketentuan tersebut, jika dalam tenggang waktu 4 (empat) bulan setelah putusan Pengadilan yang telah memperoleh kekuatan hukum tetap dikirimkan, tergugat tidak melaksanakan kewajiban untuk melakukan pencabutan Keputusan Tata Usaha Negara yang bersangkutan, maka Keputusan Tata Usaha Negara yang disengketakan itu tidak mempunyai kekuatan hukum lagi.

Lebih lanjut, apabila putusan pengadilan yang telah memperoleh kekuatan hukum tetap tidak dilaksanakan maka pada Pasal 116 ayat (4) dan ayat (5) mengatur mengenai adanya penjatuhan sanksi bagi pejabat TUN yang tidak melaksanakan putusan yang telah berkekuatan hukum tetap berupa pembayaran uang paksa (dwangsom) dan/atau sanksi administratif serta publikasi di media cetak. Dalam perkembangan selanjutnya dilakukan perubahan kedua terhadap Undang-Undang No. 5 Tahun 1986, dengan Undang-Undang No. 51 Tahun 2009 dimana di dalam Pasal 116 ayat (6) di samping diatur upaya-upaya sebagaimana diatur dalam undang-undang sebelumnya, diatur pula mengenai pelaporan ketidaktaatan Pejabat TUN untuk melaksanakan putusan Pengadilan Tata Usaha Negara tersebut kepada Presiden selaku pemegang kekuasaan pemerintahan tertinggi serta kepada lembaga perwakilan rakyat untuk menjalankan fungsi pengawasan.

Berbagai upaya yang dilakukan tersebut menunjukan bahwa upaya untuk melaksanakan putusan pengadilan yang telah memiliki kekuatan hukum tetap dalam lingkup Pengadilan Tata Usaha Negara, guna mewujudkan asas kepastian hukum belum dapat dilaksanakan secara maksimal. Banyaknya putusan PTUN yang tidak dapat dieksekusi, meskipun telah dilakukan berbagai upaya paksa sebagaimana diatur dalam Pasal 116. Sehingga pada akhirnya, Putusan PTUN yang berupa pembatalan dan memerintahkan untuk mencabut Keputusan Tata Usaha Negara (KTUN) diserahkan kembali kepada pejabat negara yang mengeluarkan KTUN tersebut. Akibatnya, dalam hal ini kepastian hukum melalui pelaksanaan putusan pengadilan yang telah memiliki kekuatan hukum yang tetap tergantung pada niat baik dari pejabat yang digugat untuk melaksanakan putusan pengadilan tersebut.

Dengan demikian, peradilan TUN sebagai lembaga tempat mencari perlindungan hukum bagi rakyat ternyata sering tidak mampu memberikan kepuasan kepada rakyat sebagai pencari keadilan atas kemenangan yang diperolehnya dalam suatu sengketa TUN. Akan tetapi, dalam praktiknya, berbagai harapan tersebut tidak sesuai dengan kenyataan yang terjadi.

Putusan pengadilan tata usaha Negara yang telah memiliki kekuatan hukum tetap, tetapi belum dapat dilaksanakan juga terdapat dalam Putusan Nomor : 13/G/2015/PTUN.ABN. Tgl 10 November 2015 dalam sengketa antara : Elisa Rieuwpassa, Julius R Rieuwpassa, dan Novi. B. Rieuwpassa (Penggugat) Melawan Saniri Negeri Sameth (Tergugat I) dan Bupati Maluku Tengah (Tergugat II), yang memutuskan bahwa:

1) Menyatakan batal Surat Keputusan Saniri Negeri Sameth Nomor : $01 / \mathrm{KPTS} / \mathrm{SNS} / 2015$ Tanggal 26 Pebruari 2015 Tentang Penetapan Kepala Pemerintah Negeri Sameth Kecamatan Pulau 
Haruku Kabupaten Maluku

Tengah ;

2) Menyatakan batal Surat

Keputusan Bupati Maluku Tengah Nomor 141-393 Tahun 2015 Tanggal 10 Maret 2015 Tentang Pengesahan Kepala Pemerintah Negeri Sameth Kecamatan Pulau Haruku ;

3) Memerintahkan Tergugat I untuk mencabut Surat Keputusan Saniri Negeri Sameth Nomor : 01/KPTS/SNS/2015 Tanggal 26 Pebruari 2015 Tentang Penetapan Kepala Pemerintah Negeri Sameth Kecamatan Pulau Haruku Kabupaten Maluku Tengah ;

4) Memerintahkan Tergugat II untuk mencabut Surat Keputusan Bupati Maluku Tengah Nomor 141-393 Tahun 2015 Tanggal 10 Maret 2015 Tentang Pengesahan Kepala Pemerintah Negeri Sameth Kecamatan Pulau Haruku

Putusan Pengadilan Tata Usaha Negara Ambon, kemudian dikuatkan melalui putusan banding pada Pengadilan Tinggi Tata Usaha Negara Makassar Nomor: $\quad$ 12/B/2016/PT.TUN.MKS Tanggal 17 Mei 2016, Menguatkan Putusan Pengadilan Tata Usaha Negara Ambon Nomor : 13/B/2015/PTUN.Abn, tanggal 10 November 2015 yang dimohonkan banding tersebut.

Dengan demikian, dalam konteks pelaksanaan putusan pengadilan TUN yang telah memiliki kekuatan hukum tetap, Negara berperan untuk memberikan manfaat yang sebesar-besarnya bagi kebahagian rakyatanya dengan cara melaksanakan putusan pengadilan yang telah memiliki kekuatan hukum tetap tersebut. Sehingga, dalam konteks putusan pengadilan TUN yang tidak dapat dilaksanakan dirasakan tidak memenuhi aspek keadilan bagi masyarakat.

\section{B. PEMBAHASAN}

\section{Kekuasaan Kehakiman Di Indonesia}

\section{Pelaksanaan Kekuasaan Kehakiman}

Istilah yudikatif, berasal dari bahasa Belanda yaitu judicatief. Dalam sistem negara modern cabang kekuasaan kehakiman merupakan cabang yang diorganisasikan secara mandiri atau tersendiri. Baik di negara-negara civil law atau common law, baik yang menganut sistem presidensil atau parlementer, lembaga kehakiman selalu bersifat tersendiri, dan bersifat independent dari pengaruh cabang-cabang kekuasaan yang lain 6 .

Terkait dengan itu, maka sebagai salah satu cabang kekuasaan yang merdeka, kekuasaan kehakiman diselenggarakan oleh badan-badan peradilan, baik itu peradilan umum, peradilan agama, peradilan militer, peradilan tata usaha negara dan Mahkamah agung sebagai peradilan tertinggi, yang bertugas untuk menerima, memeriksa dan mengadili serta menyelesaikan setiap perkara yang diajukan padanya.

Selain itu, dikenal juga beberapa pengadilan khusus baik yang bersifat tetap maupun ad hoc, diantaranya ${ }^{7}$ :

1) Pengadilan HAM

2) Pengadilan Tindak Pidana Korupsi

3) Pengadilan Niaga

4) Pengadilan Perikanan

5) Pengadilan Anak

6) Pengadilan Hubungan Industrial

7) Pengadilan Pajak

8) Mahkamah Syariah Provinsi NAD

9) Pengadilan Adat Papua

Terkait dengan Pengadilan HAM, Pengadilan Tipikor, Pengadilan Niaga,

6 Jimly, Assiddiqie. (2006). Pengantar Ilmu Hukum Tata Negara, Jilid II, Jakarta: Konstitusi Press \& Syaamil Cipta Media, h. 13

7 Ibid, h. 50-51. 
Pengadilan Perikanan, Pengadilan Anak, serta Pengadilan Hubungan Industrial dan pengadilan adat termasuk didalam lingkungan Peradilan Umum. Sedangkan pengadilan Pajak dapat digolongkan didalam lingkungan Peradilan Tata Usaha Negara. Sementara itu, Mahkamah Syariah digolongkan ke dalam Lingkungan Peradilan Agama.Selain itu, terdapat juga badan-badan quasi pengadilan yang berbentuk komisi-komisi yang bersifat ad hoc. Misalnya: komisi pengawas persaingan usaha, komisi penyiaran dan komisi banding merek $^{8}$.

\section{Pelaksanaan Kekuasaan Kehakiman Di Indonesia}

\section{1) Peradilan Umum:}

Pasal 2 UU No 8 tahun 2004 Tentang perubahan atas UU No 2 tahun 1986 Tentang Peradilan Umum menyatakan bahwa Peradilan umum adalah salah satu pelaku kekuasaan kehakiman bagi rakyat pencari keadilan pada umumnya. Sementara itu, Pasal 3 ayat (1) UU No 2 tahun 1986 menyatakan bahwa Kekuasaan Kehakiman di lingkungan Peradilan Umum dilaksanakan oleh :

(1) Pengadilan Negeri;

(2) Pengadilan Tinggi.

Sementara itu, pada ayat (2) menyatakan bahwa Kekuasaan Kehakiman di lingkungan Peradilan Umum berpuncak pada Mahkamah Agung sebagai Pengadilan Negara Tertinggi.

Terkait dengan susunan pengadilan, maka menurut Pasal 6 UU No 2 tahun 1986 menyatakan bahwa : Pengadilan terdiri dari :

(1) Pengadilan Negeri yang merupakan Pengadilan Tingkat Pertama;

\footnotetext{
${ }^{8}$ Ibid, h. 51
}

(2) Pengadilan Tinggi, yang merupakan Pengadilan Tingkat Banding.

Pasal 4 UU No 8 Tahun 2004 menyatakan bahwa:

Ayat (1) Pengadilan Negeri berkedudukan di ibukota Kabupaten/Kota, dan daerah hukumnya meliputi wilayah Kabupaten/Kota.

Ayat (2) Pengadilan Tinggi berkedudukan di ibukota Provinsi, dan daerah hukumnya meliputi wilayah Provinsi.

Pasal 50 UU No 2 tahun 1986 menyatakan bahwa Pengadilan Negeri bertugas dan berwenang memeriksa, memutus, dan menyelesaikan perkara pidana dan perkara perdata di tingkat pertama.

Sementara itu, pada Pasal 51 menyatakan bahwa:

Ayat (1) Pengadilan Tinggi bertugas dan berwenang mengadili perkara pidana dan perkara perdata di tingkat banding.

Ayat (2) Pengadilan Tinggi juga bertugas dan berwenang mengadili di tingkat pertama dan terakhir sengketa kewenangan mengadili antar Pengadilan Negeri di daerah hukumnya.

\section{2) Peradilan Agama}

Pasal 2 UU No 7 tahun 1989 tentang Peradilan Agama menyatakan bahwa Peradilan Agama merupakan salah satu pelaksana kekuasaan kehakiman bagi rakyat pencari keadilan yang beragama Islam mengenai perkara perdata tertentu yang diatur dalam Undang-undang ini.

Sementara itu, Pasal 2 UU No 3 tahun 2006 tentang Perubahan Atas UU No 7 tahun 1989 tentang Peradilan Agama menetapkan bahwa Peradilan Agama adalah salah satu pelaku kekuasaan kehakiman bagi rakyat pencari 
keadilan yang beragama Islam mengenai perkara tertentu sebagaimana dimaksud dalam Undang-Undang ini.

Dengan demikian, maka peradilan agama merupakan suatu peradilan khusus yang menangani perselisihan bagi orang-orang yang beragama islam

Menurut Bambang Sutiyoso dan Hastuti Puspita Sari 9 , dalam pelaksanaannya peradilan agama adalah lembaga yang bertugas untuk menyelenggarakan kekuasaan kehakiman guna menegakkan hukum dan keadilan yang mempunyai lingkup kewenangan:

1) Peradilan bagi rakyat pencari keadilan yang beragama islam

2) Memeriksa, memutus, dan menyelesaikan perkara perdata tertentu, yakni dibidang: perkawinan, kewarisan, wasiat, hibah yang dilakukan berdasarkan agama islam, wakaf dan sedekah.

Menurut Pasal 3 UU No 7 tahun 1989 menyatakan bahwa :

a. Kekuasaan Kehakiman di lingkungan Peradilan Agama dilaksanakan oleh :

1) Pengadilan Agama;

2) Pengadilan Tinggi Agama.

b. Kekuasaan Kehakiman di lingkungan Peradilan Agama berpuncak pada Mahkamah Agung sebagai Pengadilan Negara Tertinggi.

Terkait dengan kedudukan, maka Pasal 4 UU No 3 tahun 2006 menyatakan bahwa tempat kedudukan peradilan agama adalah:

(1) Pengadilan agama berkedudukan di ibu kota kabupaten/kota dan daerah hukumnya meliputi wilayah kabupaten/kota.

(2) Pengadilan tinggi agama berkedudukan di ibu kota provinsi

9 Sutiyoso, Bambang dan Puspita Sari, Hastuti. (2005). Aspek-aspek Perkembangan Kekuasaan Kehakiman di Indonesia, Yogyakarta: UII Press, , h. 35 dan daerah hukumnya meliputi wilayah provinsi.

\section{3) Peradilan Militer}

Menurut Bambang Sutiyoso dan Hastuti Puspita Sari peradilan militer merupakan salah satu pelaksana kekuasaan kehakiman yang mempunyai kompetensi memeriksa dan mengadili perkara-perkara pidana yang dilakukan oleh seseorang yang berstatus sebagai anggota militer atau yang dipersamakan dengan itu ${ }^{10}$.

Dalam pelaksanaannya, apabila terjadi kasus pidana militer, maka akan berlaku hukum pidana militer yang diatur dalam Kitab Undang-undang Hukum Pidana Militer (KUHPN) sebagai hukum materiil. Sedangkan hukum formilnya adalah berlakunya hukum Acara Pidana Militer dan berlaku dalam yuridiksi peradilan militer ${ }^{11}$.

Pelaksanaan kekuasaan kehakiman di lingkungan peradilan militer dilakukan oleh $^{12}$ :

(1) Mahkamah Militer (MAHMIL)

(2) Mahkamah Militer Tinggi (MAHMILTI)

(3) Mahkamah Militer Agung (MAHMILGUNG)

Pasal 8 UU No 31 Tahun 1997 Tentang Peradilan Militer menyatakan bahwa:

Ayat (1) Pengadilan dalam lingkungan peradilan militer merupakan badan pelaksana kekuasaan kehakiman di lingkungan Angkatan Bersenjata.

Ayat (2) Pelaksanaan kekuasaan kehakiman sebagaimana dimaksud pada ayat (1) berpuncak pada Mahkamah Agung sebagai Pengadilan Negara Tertinggi.

Terkait dengan Susunan Pengadilan, maka menurut Pasal 12 bahwa 
Pengadilan dalam lingkungan peradilan militer terdiri dari:

1) Pengadilan Militer;

2) Pengadilan Militer Tinggi;

3) Pengadilan Militer Utama; dan

4) Pengadilan Militer Pertempuran.

Sementara itu, pada Pasal 9 menyatakan bahwa Pengadilan dalam lingkungan peradilan militer berwenang:

1) Mengadili tindak pidana yang dilakukan oleh seseorang yang pada waktu melakukan tindak pidana adalah:
a) Prajurit;
b) yang berdasarkan undang-undang dipersamakan dengan Prajurit;

c) anggota suatu golongan atau jawatan atau badan atau yang dipersamakan atau dianggap sebagai Prajurit berdasarkan undang-undang;
d) seseorang yang tidak masuk golongan pada huruf a, huruf $\mathrm{b}$, dan huruf $\mathrm{c}$ tetapi atas keputusan Panglima dengan persetujuan Menteri Kehakiman harus diadili oleh suatu Pengadilan dalam lingkungan peradilan militer.

2) Memeriksa, memutus, dan menyelesaikan sengketa Tata Usaha Angkatan Bersenjata.

3) Menggabungkan perkara gugatan ganti rugi dalam perkara pidana yang bersangkutan atas permintaan dari pihak yang dirugikan sebagai akibat yang ditimbulkan oleh tindak pidana yang menjadi dasar dakwaan, dan sekaligus memutus kedua perkara tersebut dalam satu putusan.

Pasal 14 menetapkan bahwa Nama, Tempat Kedudukan, dan Daerah Hukum adalah

(1) Tempat kedudukan Pengadilan Militer Utama berada di Ibukota Negara Republik Indonesia yang daerah hukumnya meliputi seluruh wilayah Negara Republik Indonesia.

(2) Nama, tempat kedudukan, dan daerah hukum pengadilan lainnya ditetapkan dengan Keputusan Panglima.

(3) Apabila perlu, Pengadilan Militer dan Pengadilan Militer Tinggi dapat bersidang di luar tempat kedudukannya.

(4) Apabila perlu, Pengadilan Militer dan Pengadilan Militer Tinggi dapat bersidang di luar daerah hukumnya atas izin Kepala Pengadilan Militer Utama.

\section{4) Peradilan Tata Usaha Negara}

Pasal 4 UU No 5 Tahun 1986 jo UU No 9 tahun 2004 jo UU No 51 Tahun 2009 Tentang Peradilan Tata Usaha Negara menyatakan bahwa Peradilan Tata Usaha Negara adalah salah satu pelaksana kekuasaan kehakiman bagi rakyat pencari keadilan terhadap sengketa Tata Usaha Negara.

Sementara itu, Sengketa Tata Usaha Negara adalah sengketa yang timbul dalam bidang Tata Usaha Negara antara orang atau badan hukum perdata dengan Badan atau Pejabat Tata Usaha Negara, baik di pusat maupun di daerah, sebagai akibat dikeluarkannya Keputusan Tata Usaha Negara, termasuk sengketa kepegawaian berdasarkan peraturan perundang-undangan yang berlaku ( Pasal 1 angka 4 UU No 5 Tahun 1986). Seperti pada pengadilan lainnya, maka kekuasaan kehakiman dilingkungan peradilan tata usaha Negara terbagi atas pengadilan tingkat pertama dan tingkat banding. Pasal 5 ayat (1) menyatakan bahwa Kekuasaan kehakiman di lingkungan Peradilan Tata Usaha Negara dilaksanakan oleh :

(1) Pengadilan Tata Usaha Negara;

(2) Pengadilan Tinggi Tata Usaha Negara.

$$
\text { Sementara pada ayat }
$$


menyatakan bahwa Kekuasaan kehakiman di lingkungan Peradilan Tata Usaha Negara berpuncak pada Mahkamah Agung sebagai Pengadilan Negara Tertinggi.

Terkait dengan itu, maka menurut Pasal 6 ayat (1) bahwa Pengadilan Tata Usaha Negara berkedudukan di ibukota kabupaten/kota, dan daerah hukumnya meliputi wilayah kabupaten/kota. Sementara pada ayat (2) menyatakan bahwa Pengadilan Tinggi Tata Usaha Negara berkedudukan di ibukota provinsi, dan daerah hukumnya meliputi wilayah provinsi.

Lebih lanjut didalam Pasal 51 ayat (1) menyatakan bahwa Pengadilan Tinggi Tata Usaha Negara bertugas dan berwenang memeriksa dan memutus sengketa Tata Usaha Negara di tingkat banding.dan pada ayat (2) menyatakan bahwa Pengadilan Tinggi Tata Usaha Negara juga bertugas dan berwenang memeriksa dan memutus di tingkat pertama dan terakhir sengketa kewenangan mengadili antara Pengadilan Tata Usaha Negara di dalam daerah hukumnya. Sedangkan ayat (3) menyatakan Pengadilan Tinggi Tata Usaha Ngara bertugas dan berwenang memeriksa, memutus, dan menyelesaikan di tingkat pertama sengketa Tata Usaha Negara sebagaimana dimaksud dalam Pasal 48.

\section{5) Mahkamah Agung}

Menurut Pasal 1 UU No 14 Tahun 1985 jo UU No 5 Tahun 2004 jo UU No 3 Tahun 2009 tentang Mahkamah Agung menyatakan bahwa Mahkamah Agung adalah salah satu pelaku kekuasaan kehakiman sebagaimana dimaksud dalam Undang-Undang Dasar Negara Republik Indonesia Tahun 1945.

Sementara itu Pasal 2 menyatakan bahwa Mahkamah Agung adalah Pengadilan Negara Tertinggi dari semua Lingkungan Peradilan, yang dalam melaksanakan tugasnya terlepas dari pengaruh pemerintah dan pengaruh-pengaruh lain. Dan pada Pasal 3 mengatur mengenai kedudukan Mahkamah Agung di ibukota Negara Republik Indonesia.

Mahkamah Agung sebagai Lembaga tinggi Negara yang melaksanakan kekuasaan kehakiman dan merupakan pengadilan negara tertinggi mempunyai fungsi-fungsi sebagai berikut $^{13}$ :

(1) fungsi bidang pengadilan

(2) Fungsi bidang pengawasan

(3) fungsi bidang pemberian nasehat

(4) fungsi bidang pengaturan

(5) fungsi bidang Administrasi

(6) fungsi bidang tugas dan kewenangan lainnya.

Mahkamah Agung sebagai puncak kekuasaan peradilan menangani beberapa hal, sebagai berikut ${ }^{14}$ :

(1) Kasasi

(2) Peninjauan Kembali

(3) Sengketa wewenang Mengadili

(4) Menguji materil terhadap Peraturan Perundang-undangan di bawah Undang-undang.

(5) Memutus tingkat pertama dan terakhir semua sengketa yang timbul karena perampasan kapal asing dan muatannya oleh kapal perang Indonesia.

(6) melakukan pengawasan tertinggi atas perbuatan pengadilan dalam lingkungan peradilan yang berada dibawahnya.

(7) memberikan pertimbangan hukum kepada presiden dalam permohonan grasi dan rehabilitasi.

\section{Konsekuensi Yuridis Terhadap Pelaksanaan Putusan TUN Yang Tidak Mewujudkan Keadilan.}

Negara Indonesia adalah Negara Hukum. Hal ini diatur dalam pasal 1 ayat (3) Undang-undang Dasar Negara Republik Indonesia (UUD NRI Tahun

\footnotetext{
13 Ibid, h.43

14 Ibid, h. 43-44
} 
1945) hasil perubahan ketiga. Menurut Atamimi ${ }^{15}$, sebagai Negara yang berdasarkan atas hukum, maka hukum harus ditempatkan sebagai dasar kekuasaan Negara dan penyelenggaraan kekuasaan tersebut dalam segala bentuknya dilakukan dibawah kekuasaan hukum.

Pelaksanaan konsep Negara hukum membuat pembagian kekuasaan menjadi salah satu bagian yang berperan dalam penyelenggaraan pemerintahan. Dimana, pembagian kekuasaan memungkinkan adanya pembatasan dalam penyelenggaraan kekuasaan. Ide pembatasan kekuasaan dianggap harus ada supaya kekuasaan negara tidak terpusat di tangan satu orang atau satu organ saja. Hal ini membuat upaya pembatasan kekuasaan dibuat dengan mengadakan pembedaan dan pemisahan kekuasaan negara kedalam beberapa fungsi yang berbeda ${ }^{16}$. Sejalan dengan pandangan diatas, maka menurut Oosterhagen ${ }^{17}$ tujuan dari pemisahan kekuasaan adalah sebagai pengawasan dan pembatasan terhadap kekuasaan.

\section{Perkembangan pemikiran}

mengenai pembatasan kekuasaan didasarkan pada Pengalaman sejarah ketatanegaraan di Inggris yang menempatkan raja memegang kekuasaan yang mutlak baik itu kekuasaan eksekutif, legislatif maupun yudikatif. Penumpukan kekuasaan ini menyebabkan kekuasaan negara berada pada tangan satu orang sehingga menimbulkan kekuasaan yang absolut. Atas dasar inilah, maka

15 Atamimi, Hamid, (1992). Teori Perundang-Undangan Indonesia, Pidato Pengukuhan Jabatan Guru Besar Tetap Fakultas Hukum Universitas Indonesia, h. 8

16 Assiddiqie, Jimly. (2006). Pengantar Ilmu Hukum Tata Negara, Jilid II, Jakarta: Konstitusi Press \& Syaamil Cipta Media, h. 12

17 Juanda. (2004). Hukum Pemerintahan Daerah-Pasang Surut Hubungan Kewenangan Antara DPRD dan Kepala daerah, Bandung : Alumni, h. 14. berkembanglah pemikiran mengenai pembagian kekuasaan yang bermula dari ajaran pemisahan kekuasaan ke dalam berbagai organ pemerintahan untuk menghindari pemusatan kekuasaan pada satu oran atau satu organ pemerintahan saja $^{18}$.

Dipelopori oleh Jhon Locke dengan pemikiran awalnya mengenai perlunya pemisahan terhadap pelaksanaan suatu kekuasaan. Teori pemisahan kekuasaan mulai berkembang di eropa barat sebagai antitesa terhadap kekuasaan raja yang absolut pada abad pertengahan. Konsep atau pemikiran ini bertujuan untuk membatasi kekuasaan raja dalam membuat suatu peraturan, kemudian kewenangan tersebut diserahkan pada suatu badan kenegaraan yang berdiri sendiri ${ }^{19}$.

Ajaran Jhon Locke membagi kekuasaan negara atas tiga cabang kekuasaan, yaitu: kekuasaan membentuk Undang-undang (legislatif), kekuasaan melaksanakan undang-undang (eksekutif), termasuk didalamnya mengadili dan kekuasaan federatif adalah kekuasaan yang tidak termasuk kekuasaan legislatif dan eksekutif termasuk hubungan luar negeri ${ }^{20}$

Menurut Sjahran Basah perlindungan hukum yang diberikan merupakan qonditio sine qua non dalam menegakan hukum. Penegakan hukum merupakan qonditio sine qua non pula untuk merealisasikan fungsi hukum itu sendiri, fungsi hukum yang dimaksud adalah: (a) direktif, sebagai pengarah dalam membangun untuk membentuk masyarakat yang hendak dicapai dengan tujuan kehidupan bernegara; (b) integratif, sebagai pembina kesatuan bangsa; (c) stabilitatif, sebagai pemelihara dan

18 MD, Moh. Mahfud dalam Isra, Saldi. (2010). Pergeseran Fungsi Legislasi;Menguatnya Model Legislasi Parlementer dalam Sistem Presidensial Indonesia, Jakarta: RajaGrafindo Persada, h. 73-74.

19 Juanda, Op.cit, h. 28.

20 Ibid, h. 13 
menjaga keselarasan, keserasian, dan keseimbangan dalam kehidupan bernegara dan bermasyarakat; (d) perfektif, sebagai penyempurna baik terhadap sikap tindak administrasi negara maupun sikap tindak warga apabila terjadi pertentangan dalam kehidupan bernegara dan bermasyarakat; (e) korektif, sebagai pengoreksi atas sikap tindak baik administrasi negara maupun warga apabila terjadi pertentangan hak dan kewajiban untuk mendapatkan keadilan ${ }^{21}$.

Keadaan tersebut terkait dengan keberadaan prinsip Negara hukum, yang menekankan adanya jaminan perlindungan hukum bagi masyarakat. Franz Magnis Suseno menjelaskan apa yang dimaksud dengan gagasan dasar negara hukum, yaitu: Paham negara hukum berdasarkan keyakinan bahwa kekuasaan negara harus dijalankan atas dasar hukum yang baik dan adil. Jadi ada dua unsur dalam paham negara hukum: pertama bahwa hubungan antara yang memerintah dan yang diperintah tidak berdasarkan kekuasaan, melainkan berdasarkan suatu norma yang obyektif yang juga mengikat pihak yang memerintah. Dan kedua bahwa norma obyektif itu, hukum memenuhi syarat bukan hanya secara formal, melainkan dapat dipertahankan berhadapan dengan idea hukum. Hukum menjadi landasan segenap tindakan negara; dan hukum itu sendiri harus baik dan adil. Baik karena sesuai dengan apa yang diharapkan masyarakat dari hukum, dan adil karena maksud dasar segenap hukum adalah keadilan $^{22}$.

Dalam konteks Negara hukum maka putusan pengadilan yang telah

$21 \mathrm{http} / / / \mathrm{www}$. lemhannas.go.id / portal / in / component / content / article / 2005 - fungsi putusan-pengadilan-tata-usaha-negara-dalam-me mutar-roda-pemerintahan-analisis-putusan-no053 g1995ijptun-jkt-.html. (Diakses pada Tanggal 28 Mei 2018)

22 Suseno, Franz Magnis 2003, Etika Politik: Prinsip-Prinsip Moral Dasar Kenegaraan Modern, Jakarta: Gramedia Pustaka Utama, h. 295. memiliki kekeuatan hukum tetap harus dapat dilaksanakan sebagai perwujudan keadilan dalam Negara yang berdasarkan hukum. Menurut Friedrich Julius Stahl ${ }^{23}$ bahwa di negara hukum segala perbuatan yang merugikan setiap orang ataupun hak-hak setiap orang dapat diawasi pengadilan, sedangkan review-nya (peninjauan kembali) dapat disalurkan melalui Pengadilan Tata Usaha Negara. Dalam hal ini, Peradilan Tata Usaha Negara merupakan sarana control on the administration.

\section{Akibat Hukum Terhadap Tidak Dilaksanakan Putusan PTUN.}

Menurut sifatnya, Putusan Pengadilan Tata Usaha Negara dapat berupa putusan deklaratoir yaitu yang bersifat menerangkan saja. Putusan konstitutif yaitu yang bersifat meniadakan atau menimbulkan keadaan hukum yang baru dan putusan condemnatoir yaitu bersifat penghukuman atau berisi kewajiban untuk melakukan tindakan tertentu terhadap yang kalah. Menurut ketentuan Pasal 97 ayat (7) Undang-Undang No. 5 Tahun 1986 tentang Peradilan Tata Usaha Negara, putusan Peradilan Tata Usaha Negara dapat berupa: Gugatan ditolak, Gugatan dikabulkan, Gugatan tidak diterima dan Gugatan gugur. Dari macam isi dan sifat putusan Pengadilan Tata Usaha Negara tersebut tidak semua putusan dapat dikenakan Upaya Paksa melainkan hanya putusan putusan yang memenuhi syarat saja, antara lain:

a. Putusan yang menyatakan gugatan dikabulkan, yaitu apabila dari hasil pemeriksaan di persidangan ternyata dalil-dalil dari posita

${ }^{23} \mathrm{http}: / / w w w . f a k u l t a s h u k u m$ - universitas panjisakti.com / component / content/article / 5-bahan / 32 - bahan - kuliah - ptun.html. (Diakses pada Tanggal 28 Mei 2018). 
gugatan Penggugat telah terbukti secara formal maupun materiil dan telah dapat mendukung petitum yang dikemukakan Penggugat;

c. Putusan bersifat condemnatoir, yaitu putusan yang sifatnya memberikan beban atau kewajiban untuk melakukan tindakan tertentu kepada Badan/Pejabat Tata Usaha Negara seperti:

1) Kewajiban mencabut Keputusan Tata Usaha Negara yang dinyatakan batal/tidak sah.

2) Kewajiban menerbitkan Keputusan Tata Usaha Negara badan/pengganti.

3) Kewajiban mencabut dan menerbitkan Keputusan Tata Usaha Negara yang baru.

4) Kewajiban membayar ganti rugi.

5) Kewajiban melaksanakan rehabilitasi dalam sengketa kepegawaian.

Putusan yang telah memperoleh kekuatan hukum tetap (inkracht Van Gewijsde), yaitu putusan pengadilan yang tidak dapat diterapkan upaya hukum lagi terhadap putusan tersebut.

Pelaksanaan suatu putusan pengadilan dalam kehidupan bernegara khususnya negara hukum sangat penting demi menjamin adanya kepastian hukum yang berkeadilan. Suatu keputusan Pengadilan Tata Usaha Negara yang telah berkekuatan hukum tetap tidak dapat diganggu gugat lagi, maksudnya dapat dilaksanakan dan harus ditaati oleh siapa pun juga termasuk Pemerintah. Hanya putusan Pengadilan yang telah memperoleh kekuatan hukum tetap (inkracht van gewisde) yang dapat dilaksanakan.

Pasal 116 Undang-Undang Nomor 9 Tahun 2004 menyatakan sebagai berikut: a) Salinan putusan Pengadilan yang telah memperoleh kekuatan hukum tetap, dikirimkan kepada para pihak dengan surat tercatat oleh Panitera Pengadilan setempat atas perintah Ketua Pengadilan yang mengadilinya dalam tingkat pertama selambat-lambatnya dalam waktu empat belas hari.

b) Dalam hal empat bulan setelah putusan Pengadilan yang telah memperoleh kekuatan hukum tetap sebagaimana dimaksud dalam ayat (1) dikirimkan tergugat tidak melaksanakan kewajibannya sebagaimana dimaksud dalam Pasal 97 ayat (9) huruf a, maka Keputusan Tata Usaha Negara yang disengketakan itu tidak mempunyai kekuatan hukum lagi.

c) Dalam hal tergugat ditetapkan harus melaksanakan kewajibannya sebagaimana dimaksud dalam Pasal 97 ayat (9) huruf b dan huruf c dan kemudian setelah 3 (tiga) bulan ternyata kewajiban tersebut tidak dilaksanakannya penggugat mengajukan permohonan kepada Ketua Pengadilan sebagaimana dimaksud pada ayat (1) agar Pengadilan memerintahkan tergugat melaksanakan putusan Pengadilan tersebut.

d) Dalam hal tergugat tidak bersedia melaksanakan putusan Pengadilan yang telah memperoleh kekuatan hukum tetap, terhadap pejabat yang bersangkutan dikenakan upaya paksa berupa pembayaran sejumlah uang paksa dan/atau sanksi administratif.

e) Pejabat yang tidak melaksanakan putusan pengadilan sebagaimana dimaksud pada ayat diumumkan pada media massa cetak setempat oleh Panitera sejak tidak terpenuhinya ketentuan sebagaimana dimaksud pada ayat (3). 
Peradilan TUN sebagai lembaga tempat mencari perlindungan hukum bagi rakyat ternyata sering tidak mampu memberikan kepuasan kepada rakyat sebagai pencari keadilan atas kemenangan yang diperolehnya dalam suatu sengketa TUN

Putusan adalah inti dan tujuan dari rangkai kegiatan proses peradilan, memuat penyelesaian perkara yang sejak awal membebani para pihak yang merasa dirugikan. Hakim wajib memutus bagian dari tuntutan tetapi hakim dilarang melebihi dari tuntutan atau hal-hal yang tidak dituntut.

Ada tiga jenis putusan akhir menurut sifatnya ${ }^{24}$ :

a. Putusan bersifat pembebanan (condemnatoir), Putusan yang mengandung pembebanan

b. Putusan yang bersifat pernyataan (declaratoir), Putusan yang hanya menegaskan suatu keadaan hukum yang sah.

c. Putusan yang bersifat penciptaan (constitutief), Putusan yang melenyapkan suatu keadaan hukum atau melahirkan atau menciptakan suatu keadaan hukum baru.

Putusan akhir adalah putusan yang dijatuhkan oleh hakim setelah pemeriksaan sengketa tata usaha negara selesai yang mengakhiri sengketa tersebut. Dalam Pasal 97 ayat (2) diketahui bahwa putusan akhir dapat berupa:

a. Gugatan ditolak

Putusan yang berupa gugatan yang ditolak adalah putusan yang menyatakan bahwa Keputusan Tata Usaha Negara yang menimbulkan sengketa tata usaha negara adalah Keputusan Tata Usaha Negara yang tidak dinyatakan batal atau sah.

24 Prodjohamidjojo, Martiman. (1996) Hukum Acara Peradilan Tata Usaha Negara, Jakarta: Ghalia Indonesia, h.112. b. Gugatan tidak diterima

Putusan yang berupa gugatan tidak diterima adalah putusan yang menyatakan syarat-syarat yang telah ditentukan tidak dipenuhi oleh gugatan yang diajukan oleh Pengggugat. Diktum putusan ini sebenernya bersifat deklatoir, yang tidak membawa perubahan apa-apa dalam hubungan hukum yang ada antara penggugat dengan tergugat.

c. Gugatan gugur

Putusan yang berupa gugatan gugur adalah putusn yang dijatuhkan hakim karena penggugat tidak hadir dalam beberapa kali sidang, meskipun telah dipanggil denagn patut atau penggugat telah meninggal dunia.

d. Gugatan dikabulkan

Putusan yang berupa gugatan dikabulkan adalah putusan yang menyatakan Keputusan Tata Usaha Negara yang menimbulkan Sengketa Tata Usaha Negara adalah Keputusan Tata Usaha Negara yang dinyatakan tidak sah atau batal.

Terkait dengan itu, maka keputusan pengadilan yang mempunyai kekuatan hukum tetap yang dapat dilaksanakan. Putusan Pengadilan yang telah mempunyai hukum tetap adalah:

a. Putusan pengadilan tingkat pertama yang sudah tidak dapat dilawan atau dimintakan pemeriksaan banding lagi;

b. Putusan pengadilan tinggi yang sudah tidak dimintakan pemeriksaan kasasi lagi; dan

c. Putusan MA dalam tingkat kasasi.

Suatu putusan dapat dijalankan apabila putusan tersebut telah memperoleh dan berkekuatan hukum tetap. Penetapan hubungan hukum antara kedua belah pihak yang bersengketa itu sudah dapat ditarik kembali atau tidak 
bisa diubah lagi karena sudah tertutup upaya hukum sehingga putusan demikian mempunyai kekuatan eksekutorial. ${ }^{25}$

\section{PE N U T U P}

Akibat Hukum tidak terwujudnya keadilan dalam pelaksanaan putusan pengadilan TUN oleh pejabat pemerintah, maka tindakan pejabat pemerintahan tersebut adalah tindakan sewenang wenang.

\section{DAFTAR PUSTAKA}

Abdullah, Rozali. (2005). Hukum Acara Peradilan Tata Usaha Negara. Jakarta: RajaGrafndo Persada.

Assiddiqie, Jimly. (2006). Pengantar Ilmu Hukum Tata Negara, Jilid II, Jakarta: Konstitusi Press \& Syaamil Cipta Media.

Juanda. (2004). Hukum Pemerintahan Daerah-Pasang Surut Hubungan Kewenangan Antara DPRD dan Kepala daerah, Bandung : Alumni.

MD, Moh. Mahfud dalam Isra, Saldi. (2010). Pergeseran Fungsi Legislasi;Menguatnya Model Legislasi Parlementer dalam Sistem Presidensial Indonesia, Jakarta: RajaGrafindo Persada.

Prodjohamidjojo, Martiman. (1996) Hukum Acara Peradilan Tata Usaha Negara, Jakarta: Ghalia Indonesia.

Suseno, Franz Magnis 2003, Etika Politik: Prinsip-Prinsip Moral Dasar Kenegaraan Modern, Jakarta: Gramedia Pustaka Utama.

Sutiyoso, Bambang dan Puspita Sari, Hastuti. (2005). Aspek-aspek Perkembangan Kekuasaan Kehakiman di Indonesia, Yogyakarta: UII Press.
Sibuea, Hotma. (2010). Asas Negara Hukum, Peraturan kebijakan dan Asas-asas Umum Pemerintahan Yang Baik, Jakarta: Erlangga.

\section{Lain-Lain}

Atamimi, Hamid, (1992). Teori Perundang-Undangan Indonesia, Pidato Pengukuhan Jabatan Guru Besar Tetap Fakultas Hukum Universitas Indonesia.

Asshiddiqie, Jimly Gagasan Negara Hukum Indonesia, http://www.docudesk.com.

Rikardo, Simarmata, 2012. Pemenuhan indikator Negara Hukum dalam putusan pengadilan berkaitan dengan sumber daya alam dan lingkungan hidup, Kertas Kerja Epistema No.10/2012, Epistema Institute, Jakarta: (http://epistema.or.id/indikator $\square$ negara $\square$ hukum).

http://www.lemhannas.go.id / portal / in / component / content / article / 2005 - fungsi

putusan-pengadilan-tata-usaha-nega ra-dalam-memutar-roda-pemerintah an-analisis-putusan-no053g1995ijpt un-jkt-.html.

http://www.fakultashukum - universitas panjisakti.com / component / content/article / 5-bahan / 32 bahan - kuliah - ptun.html.

25 Ibid. h. 107. 